\title{
A Novel Solution for Biogas Applications in Poultry Industry: CLAMBS approach
}

Duygu Karaalp ${ }^{1}$, Nurdan Doruk², Nadir Dizge ${ }^{2}$, Bülent Keskinler ${ }^{2}$ and Nuri Azbar ${ }^{3 *}$

${ }^{1}$ Ege University, Graduate School of Natural and Applied Sciences, Biotechnology Department, 35100 Izmir, Turkey

${ }^{2}$ Gebze Institute of Technology, Department of Environmental Engineering, 41400 Kocaeli, Turkey

${ }^{3}$ Ege University, Engineering Faculty, Bioengineering Department, 35100 Izmir, Turkey

\begin{abstract}
Chicken manure has high solid and high ammonia content which dictates the dilution of feed material with huge amount of freshwater in order to minimize ammonia toxicity, if it is to be digested alone. In this study, a novel approach is presented to significantly minimize fresh water need for biogas application and to eliminate the construction of costly digestate storage tanks. For this purpose, membrane process which allows recycling of digestate after ammonia removal was integrated to the conventional biogas system. Therefore, the selection of proper membranes for the removal of ammonia from digestate was carried out by testing six different types of Nano Filtration (NF) membranes (NF270, NF245, NF200, NF90, NF-NF, NP010) and three different types of Reverse Osmosis (RO) membranes (BW30, SW30, $\mathrm{X} 20$ ) in cross flow microfiltration experiments. The performance of the membranes was tested by monitoring parameters such as $\mathrm{pH}$, conductivity, COD, TN, NO2-N, NO3-N, TP in the permeate under various operating conditions. NF90 $(83 \%)$ and X20 (92\%) type membranes were found to be most effective for the removal of TN from the digestate. Moreover, COD (Chemical Oxygen Demand) removal efficiency reached up to $99 \%$ for both NF90 and X20 membrane.
\end{abstract}

Keywords: Poultry waste; Ammonia removal; Chicken manure waste; Cross-flow membrane filtration; Reverse osmosis

\section{Introduction}

Poultry sector is one of the most important agricultural activities which generates huge amount of organic waste that needs environmentally friendly management all over the world. Uncontrolled discharges and inappropriate management of chicken manure results in serious environmental deterioration leading to eutrophication of surface waters and pollution of soil as well as ground water [1]. The discharge of ammonia rich chicken manure into receiving media could be toxic for aquatic life even at very low concentration [2-4]. Chicken manure is quite suitable for anaerobic digestion since it has a higher proportion of biodegradable organic matter than the excrements of any other livestock [5]. Even though, ammonia is essential for the stability of digestion process, high ammonia is frequently reported as the primary cause of digester failure because of its direct inhibiton to microbial activity, especially when chicken manure is digested alone [6,7]. Several methods have been developed for ammonia removal including nitrification-denitrification processes [8,9], ANAMOX [10], ion exchange processes using natural or synthetic adsorbents $[11,12]$, breakpoint chlorination [13], air stripping [14], and membrane processes [15-19]. On the other hand, most commonly applied approach in order to eliminate the negative effect of high ammonia content of chicken manure during anaerobic digestion is either the dilution of raw chicken manure with continuous addition of freshwater or co-digestion with other alternative organic substrates which have lower ammonia content [20]. The both alternatives have their inherent disadvantages; i) the addition of huge level of fresh water require the construction of very large tanks for the storage of residual digestate (at least for 5 months) until it can be used on arable lands as fertilizer. This approach requires high capital cost for the construction of storage basins. ii) Co-substrates are not so easily available or not accessible with a reasonable cost. Therefore, recycling of digestate after removing ammonia by membrane filtration seems to be logical solution, since this method can significantly reduce amount of fresh water needed and eliminate the construction of costly storage basins. In order to realize the aforementioned solution introduced for the first time in this study, the selection of appropriate membranes that will be integrated to conventional biogas flow scheme was carried out. For this purpose, the effectiveness of six different Nano Filtration (NF) and three different reverse osmosis (RO) membranes in terms of ammonia removal from chicken manure was investigated using cross-flow membrane filtration system. The performance of the membranes was tested by monitoring various parameters such as $\mathrm{pH}$, conductivity, $\mathrm{COD}, \mathrm{TN}, \mathrm{NO}_{2}-\mathrm{N}$, $\mathrm{NO}_{3}-\mathrm{N}, \mathrm{TP}$ in the permeate under various operating conditions. In addition, the effects of various operating conditions such as filtration pressure and filtration temperature on the filtration flux and rejection efficiency were also studied for the best RO membrane type. To the best of our knowledge, as of today, there are no reports of previous studies on chicken manure digestion coupled to ammonia removal by a membrane filtration and recycling of digestate for use as fresh water in a single reactor system.

\section{Materials and Methods}

\section{Source and characteristics of chicken manure}

The chicken manure (laying hen) used in this study was kindly obtained from a local chicken farm in Adapazarı, Sakarya, Turkey. The pollution characteristics of the manure are given in Table 1 . All the chicken manure was stored in a refrigerator at $+4^{\circ} \mathrm{C}$ until used.

\section{Specifications of membranes used in the experiments}

The properties of the six NF (NF90, NF200, NF245, NF270, NF-

*Corresponding author: Nuri Azbar, Professor, Faculty of Engineering Bioengineering Department, Ege University, Izmir, Turkey, Tel: 232-388-4955 E-mail: nuri.azbar@ege.edu.tr

Received December 15, 2014; Accepted January 12, 2015; Published January 16,2015

Citation: Karaalp d, Doruk N, Dizge N, Keskinler B, Azbar N (2015) A Nove Solution for Biogas Applications in Poultry Industry: CLAMBS approach. J Bioprocess Biotech 5: 200 doi:10.4172/2155-9821.1000200

Copyright: ( $) 2015$ Karaalp d, et al. This is an open-access article distributed under the terms of the Creative Commons Attribution License, which permits unrestricted use, distribution, and reproduction in any medium, provided the original author and source are credited. 


\begin{tabular}{|c|c|}
\hline Parameters & Value \\
\hline $\mathrm{pH}$ & $8.2 \pm 0.1$ \\
\hline Conductivity $(\mathrm{mS} / \mathrm{cm})$ & $7.30 \pm 0.8$ \\
\hline $\mathrm{SS}(\mathrm{mg} / \mathrm{L})$ & 1072 \\
\hline $\mathrm{COD}(\mathrm{mg} / \mathrm{L})$ & $4610 \pm 258$ \\
\hline $\mathrm{NO}_{2}{ }^{-} \mathrm{N}(\mathrm{mg} / \mathrm{L})$ & $2.8 \pm 0.5$ \\
\hline $\mathrm{NO}_{3}{ }^{-} \mathrm{N}(\mathrm{mg} / \mathrm{L})$ & $107.9 \pm 7.2$ \\
\hline $\mathrm{NH}_{4}{ }^{+}-\mathrm{N}(\mathrm{mg} / \mathrm{L})$ & $656 \pm 78.3$ \\
\hline $\mathrm{TN}(\mathrm{mg} / \mathrm{L})$ & $1182 \pm 29.5$ \\
\hline $\mathrm{TP}(\mathrm{mg} / \mathrm{L})$ & $65 \pm 2.8$ \\
\hline Water content $(\%)$ & $74 \pm 1.5$ \\
\hline Dry matter $(\%)$ & $26 \pm 1.5$ \\
\hline
\end{tabular}

Table 1: Characteristic parameters of chicken manure (Dry matter concentration of the feed: $3 \%$ DM)

NF, NP010) and three RO (BW30, SW30, X20) membranes used in the study are described in Table 2. Prior to the experiments, all of the membrane sheets were conditioned with deionized water. In each experiment, a new membrane was used to obtain reproducible results.

\section{Experimental set up and procedures}

All the membrane selection experiments were carried out by a labscale cross-flow flat sheet system (custom made) shown in Figure 1. The system was composed of a high pressure piston pump (adjustable flow rate: $100-600 \mathrm{~L} / \mathrm{h}$; pressure up to $60 \mathrm{bar}$ ) with a frequency converter, a stainless steel feed tank $(60 \mathrm{~L})$, a membrane unit $(20 \mathrm{~cm}$ (length) $\times$ $4 \mathrm{~cm}$ (width)), a temperature control unit and a control panel (PLC) with an emergency stop button. The chicken manure solution in the feed tank was fed into the dismountable flat sheet membrane module by the help of the piston pump after micro filtration (pore size $10 \mu \mathrm{m}$ ). The temperature of the feed tank was kept at a desired level by the help of a heat exchange. The feed flow rate was regulated via a valve installed before the module. The cross flow velocity was kept constant at 2.0 $\mathrm{m} / \mathrm{s}$ throughout the experiments. The pressure gauges (0-100 bar and $20 \mathrm{~mA}$ signal output) were installed at the inlet and the outlet of the module. The permeate liquid was weighted by an electrical balance and the data were transferred to a personal computer at intervals of $1 \mathrm{~min}$. The values of permeate flux were calculated from the change in the volume of permeate liquid with time and the effective membrane area. The retentate flow was continuously recycled back to the feed tank after passing through the flow meter (flow range: $0-1000 \mathrm{~L} / \mathrm{h}$ ). The system had also a by-pass line for maintenance requirement.

The rejection of contaminants was determined as follows:

$$
R(\%)=\left(1-\frac{C_{\text {permeate }}}{C_{\text {feed }}}\right) \times 100 \%
$$

Where $\mathrm{R}$ is the rejection ratio, $\mathrm{C}_{\text {feed }}$ and $\mathrm{C}_{\text {permeate }}$ are the contaminant concentration of feed and permeate, respectively.

\section{Analytical methods}

The parameters such as $\mathrm{pH}$, conductivity, $\mathrm{COD}, \mathrm{TN}, \mathrm{NO}_{2}-\mathrm{N}$, $\mathrm{NO}_{3}-\mathrm{N}, \mathrm{NH}_{4}-\mathrm{N}, \mathrm{TP}$ were measured according to "Standard Methods for the Examination of Water and Wastewater". TN was measured by Hach Lange kit. All chemical solutions were prepared with deionized water (Milli-Q' Ultrapure Water Purification System, Millipore Corp.) having conductivity less than $18.2 \mu \mathrm{S} / \mathrm{cm}$. $\mathrm{pH}$ and conductivity values were monitored by a $\mathrm{pH}$ meter (WTW multi 340i) and conductivity meter (HachLange, 2100P), respectively.

\section{Results and Discussions}

\section{Membrane selection experiments}

Literature has significant number of reports dominantly on membrane filtration of pig and cow manure with a limited report on chicken manure, on the other hand, these results must be compared cautiously, because feed characteristics, concentration factor, and experimental set-ups (fluctuating vs. stabilized temperature, fixed vs. variable pressure, tangential flow velocities, length of experimental runs) were highly variable and not always well defined. It is also well known that each membrane has its own specific characteristics and performance values as a function of varying feed solutions. The relationship between the membrane performance and the membrane characteristics depending on feed solution characteristics is still not clear, therefore, the selection of membrane type for each new feed solution in membrane filtration is very important issue for any membrane study. In this study, laying hen manure was chosen as the specific feed solution to find out to most appropriate membranes. For this purpose, six NF membranes (NF90, NF200, NF245, NF270, NF-NF, NP010) and three RO membranes (BW30, SW30, X20) were evaluated in regards to their separation performance (primarily ammonia and TN removal) in this study.

Figures $2 \mathrm{a}$ and $2 \mathrm{~b}$ show the flux values by time during the filtration of chicken manure for each nano-filtration and reverse osmosis membranes studied, respectively. The filtration pressures were 15 bars for NF membranes and 30 bar for RO membranes. The results in Figure 2a showed that the NF membranes reached pseudo-steady values at different filtration time indicating that initial and steady-state membrane fouling occurred depending on membrane type. Initially, a sharp drop in the permeate flux occurred for all nano-filtration membranes within the first twenty minutes of filtration. NP010 and NF200 membranes showed the most rapid decline in the flux among all other NF membranes studied. This rapid decline in flux was possibly attributed to initial deposition of the contaminants on membrane surface. Similar declining pattern as a result of initial pore restriction and compound adsorption on the membrane surface have also been reported in a previous study by some researchers [21,22]. Steadystate permeate flux values for NF245, NF270, NP010, NF200, NF90, and NF-NF were measured as $29.4,24.9,19.6,18.4,11.5$, and $3.7 \mathrm{~L} /$ $\mathrm{m}^{2} / \mathrm{h}$, respectively (Table 3 ). NF245 membrane yielded the greatest steady-state flux value followed by NF270, NP010, NF200, while NF90 and NF-NF membranes had the lowest steady-state flux. However, the difference between NP010 and NF200 membranes was relatively insignificant. These varying flux values for each membrane are most likely to be the result of morphological differences of membranes. The roughness, the membrane surface zeta potential, and the pore structure might change following the membrane fouling. Figure $2 \mathrm{~b}$ shows the permeate flux of manure versus filtration time for RO membranes. Similar to NF membrane studies, initial sharp drop in the permeate flux occurred for all the RO membranes approximately within the first sixty minutes of operation. X20 membrane showed the most rapid decline in the flux among all RO membranes. Steady state permeates flux values for BW30, SW30, and X20 membranes were 11.0, 15.7, and $19.6 \mathrm{~L} / \mathrm{m}^{2} / \mathrm{h}$, respectively. X 20 membrane yielded the greatest steadystate flux value followed by SW30 and BW30.

\section{Effect of trans-membrane pressure and temperature on filtration performance}

Further optimization studies for temperature and pressure were carried out using X20 membrane, since X20 RO membrane, which 
Citation:Karaalp d, Doruk N, Dizge N, Keskinler B, Azbar N (2015) A Novel Solution for Biogas Applications in Poultry Industry: CLAMBS approach. J Bioprocess Biotech 5: 200 doi:10.4172/2155-9821.1000200

Page 3 of 6

\begin{tabular}{|c|c|c|c|c|c|c|c|}
\hline $\begin{array}{l}\text { Designation } \\
\text { (SKU) }\end{array}$ & Manufactuer & Membrane Type & $\begin{array}{l}\text { Molecular Weight } \\
\text { Cut-off (MWCO) }\end{array}$ & $\begin{array}{l}\text { Salt rejection } \\
(\%)\end{array}$ & $25^{\circ} \mathrm{C}$ pH Range & $\begin{array}{c}\text { Maximum Operatin } \\
\text { Pressure }\end{array}$ & $\begin{array}{c}\text { Maximum } \\
\text { Operating } \\
\text { Temperature }\end{array}$ \\
\hline NF-NF & Dow Filmtec & Polyamide & $\sim 200-400 \mathrm{D}$ & $99-\mathrm{MgSO}_{4}$ & $2-11$ & - & - \\
\hline NF245 & Dow Filmtec & Polyamide & $\sim 200-400 \mathrm{D}$ & $99-\mathrm{MgSO}_{4}$ & $2-11$ & 800 psi (54.8 bar) & $122^{\circ} \mathrm{F}\left(50^{\circ} \mathrm{C}\right)$ \\
\hline NF270 & Dow Filmtec & Polyamide & $\sim 200-400 \mathrm{D}$ & $99.2-\mathrm{MgSO}_{4}$ & $2-11$ & 600 psi (41 bar) & $113^{\circ} \mathrm{F}\left(45^{\circ} \mathrm{C}\right)$ \\
\hline NF90 & Dow Filmtec & Polyamide & $\sim 200-400 \mathrm{D}$ & $>97.0 \mathrm{MgSO}_{4}$ & $2-11$ & 600 psi (41 bar) & $113^{\circ} \mathrm{F}\left(45^{\circ} \mathrm{C}\right)$ \\
\hline NF200 & Dow Filmtec & $\begin{array}{c}\text { Poly piperazineamide } \\
\text { sulfonated }\end{array}$ & $\sim 200-400 \mathrm{D}$ & $50-65 \mathrm{CaCl}_{2}$ & $3-10$ & 600 psi (41 bar) & $113^{\circ} \mathrm{F}\left(45^{\circ} \mathrm{C}\right)$ \\
\hline NP010 & $\begin{array}{l}\text { Microdyn Nadir, } \\
\text { GmbH }\end{array}$ & Polyethersulfone & $\sim 100 \mathrm{D}$ & $25-40 \mathrm{Na}_{2} \mathrm{SO}_{4}$ & $1-14$ & - & $95^{\circ} \mathrm{C}$ \\
\hline BW30 & Dow Filmtec & Polyamide & $100 \mathrm{D}$ & $99,70 \mathrm{NaCl}$ & $2-11$ & 600 psi (41 bar) & $113^{\circ} \mathrm{F}\left(45^{\circ} \mathrm{C}\right)$ \\
\hline SW30 & Dow Filmtec & Polyamide & $100 \mathrm{D}$ & $99.4 \mathrm{NaCl}$ & $2-11$ & 1,000 psi (69 bar) & $113^{\circ} \mathrm{F}\left(45^{\circ} \mathrm{C}\right)$ \\
\hline $\mathbf{X 2 0}$ & TriSep Corporation & Polyamide- urea & $50-100 \mathrm{D}$ & $99.5 \mathrm{NaCl}$ & - & 600 psi (41 bar) & - \\
\hline
\end{tabular}

Table 2: Characteristics of NF and RO membranes

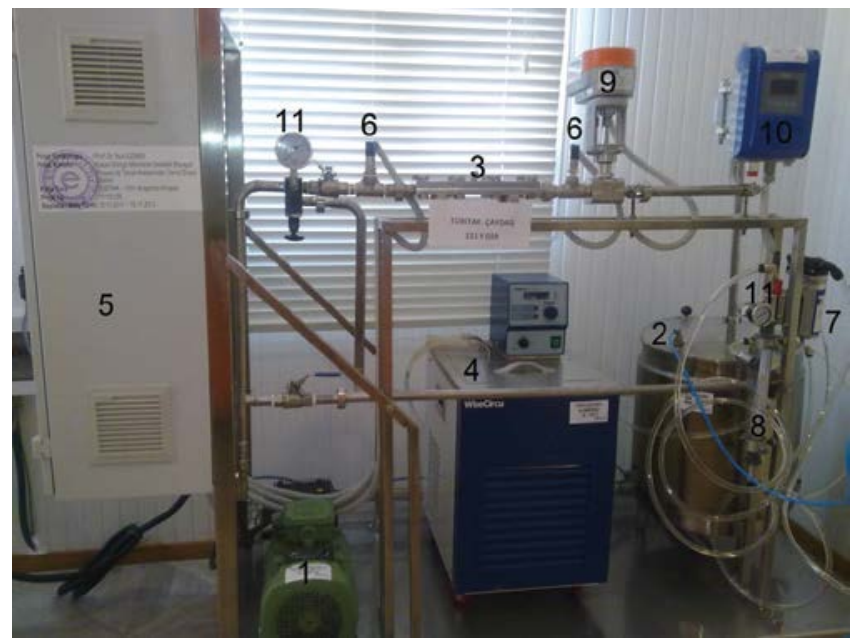

Figure 1: The experimental setup of the cross-flow membrane filtration system (1: High pressure piston pump; 2: Feed tank; 3: Flat sheet membrane module 4: Temperature control unit; 5: Control panel (PLC); 6: Pressure transducers 7: Ultrafiltration pump; 8: Ultrafiltration Unit; 9: Needle valve; 10: Flow meter; 11: Pressure gauge)

yielded the best ammonia removal, was considered as the candidate membrane for field scale application. The optimization experiments were carried out at a constant cross flow velocity $(2.0 \mathrm{~m} / \mathrm{s})$ using Trans Membrane Pressures (TMP) of 10, 15, 20, 30 bar and temperatures of $25,30,35^{\circ} \mathrm{C}$, respectively. The permeate flux profile as a function of time under different feed pressures is presented in Figure 3a. The steady-state permeate flux increased at 10 bar, possibly due to the fact that low feed pressure decreased concentration polarization and organic matter absorption on membrane surface. It was also seen that the steady-state permeate flux of the X 20 membrane increased with increasing feed pressure for 15, 20, 30 bar. The application of high pressures are known to result in higher initial permeates flux due to increase in effective number of pores upon opening up a number of closed pores. On the other hand, the nanocolloids or inorganic scaling can close the open pores situated in the active layer structure of the RO membranes [23]. As clearly seen from the Figure 3, higher the pressures, higher the flux decline occurred due to increased fouling. In addition, the concentration polarization can be dominant at higher pressures, particularly at 20 and 30 bars. Similar results have also been reported in a previous study [24]. In general, as TMP increases, concentration polarization also increases and flux decreases [25]. As the feed pressure increased from 15 bar to $30 \mathrm{bar}$, the steady-state permeate flux of the membrane increased from around $14.7 \mathrm{~L} / \mathrm{m}^{2} \mathrm{~h}$ to $19.6 \mathrm{~L} / \mathrm{m}^{2} \mathrm{~h}$, while

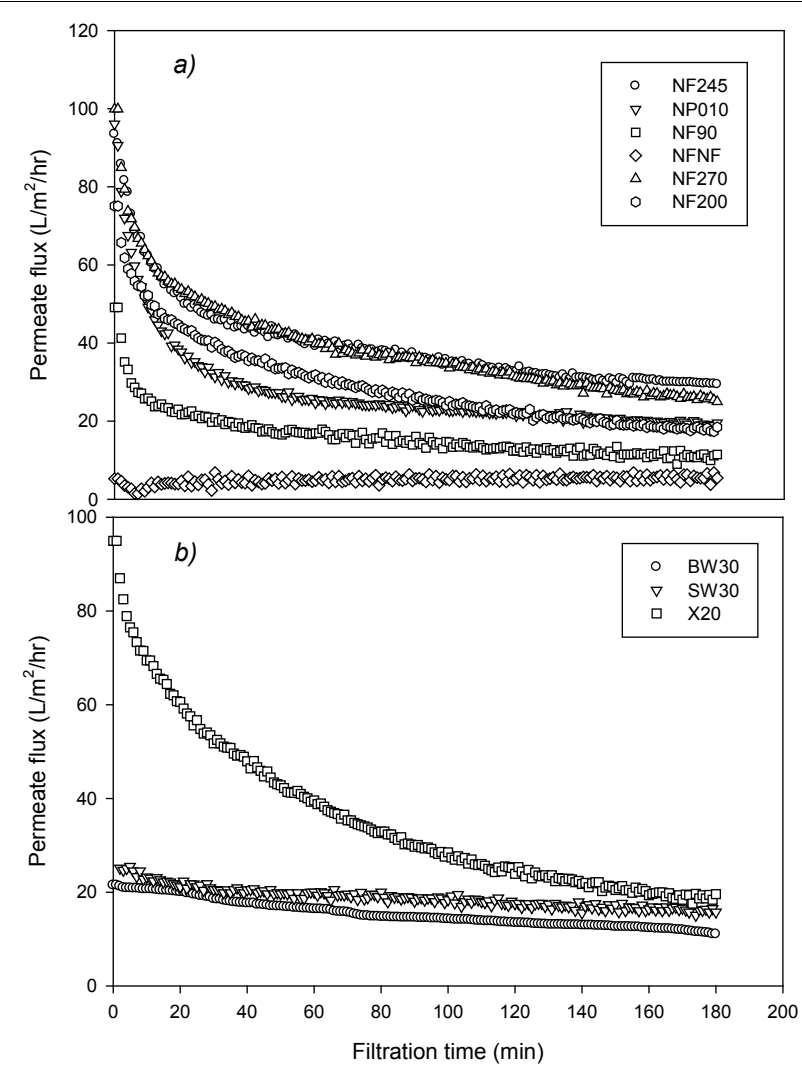

Figure 2: Variation of fluxes with time (a) for different NF membranes $(P=15$ bar), (b) for different $R O$ membranes ( $P=30$ bar)

the steady-state permeate flux of the membrane increased slowly about $29.7 \mathrm{~L} / \mathrm{m}^{2} \mathrm{~h}$ at 10 bar.

In order to select the best filtration temperature for the feed solution, the solution temperature was adjusted to $25,30,35^{\circ} \mathrm{C}$, respectively. Figure $3 \mathrm{~b}$ shows the effect of temperature on permeate flux for each temperature at 10 bar pressure which is chosen due to its stable flux value throughout the filtration period and highest steady state flux value. High temperature conditions not only improved the flux but also increased mean pore radii and the molecular weight cut off suggesting changes in the structure and morphology of the polymer matrix compressing the membrane barrier layer [26]. Even though, it is expected to have higher membrane flux at higher temperatures due to reduction in viscosity, the highest permeate flux was obtained at $30^{\circ} \mathrm{C}$ in our study and there was no difference between $25^{\circ} \mathrm{C}$ and $35^{\circ} \mathrm{C}$. 


\begin{tabular}{|c|c|c|c|c|c|c|c|}
\hline Membrane Type & Conductivity (mS/cm) & COD (mg/L) & $\mathrm{NO}_{3}-\mathrm{N}(\mathrm{mg} / \mathrm{L})$ & $\mathrm{NO}_{2}^{-}-\mathrm{N}(\mathrm{mg} / \mathrm{L})$ & $\mathrm{NH}_{4}^{+}-\mathrm{N}(\mathrm{mg} / \mathrm{L})$ & $\mathrm{TN}$ (mg/L) & $\mathrm{TP}$ (mg/L) \\
\hline NF-NF & 1.84 & $248(95)$ & 6.10 & $0.047(98)$ & $156 \quad(76)$ & $213(82)$ & $0.305(99)$ \\
\hline NP010 & 6.46 & $976(79)$ & $22.92 \quad(79)$ & $0.036 \quad(99)$ & $584 \quad(11)$ & $1090(8)$ & $0.498(99)$ \\
\hline NF200 & 4.62 & $688(85)$ & $(93)$ & $0.024(99)$ & $528 \quad(20)$ & $605(49)$ & $0.310(99)$ \\
\hline NF90 & 1.52 & $68 \quad(99)$ & 2.61 & $0.012(99)$ & $116 \quad(82)$ & $206(83)$ & $0.259(99)$ \\
\hline NF270 & 5.11 & $352(93)$ & 8.21 & $0.022(99)$ & $408 \quad(38)$ & $630(47)$ & $0.302(99)$ \\
\hline NF245 & 4.80 & $344(93)$ & 6.69 & $0.019(99)$ & $428 \quad(35)$ & $635(46)$ & $0.259(99)$ \\
\hline BW30 & 0.83 & 34 (99) & 0.97 & $0.013(99)$ & $(89)$ & $141(88)$ & $0.071(99)$ \\
\hline SW30 & 0.77 & $24 \quad(99)$ & (99) & $0.008(99)$ & $(87)$ & $175(85)$ & $0.020(99)$ \\
\hline $\mathbf{X} 20$ & 0.27 & $27 \quad(99)$ & 0.26 & $0.003(99)$ & (97) & $93(92)$ & $0.017(99)$ \\
\hline
\end{tabular}

*values in paranthesis are \% removals

Table 3: Results of analysis for permeate samples for each membranes studied
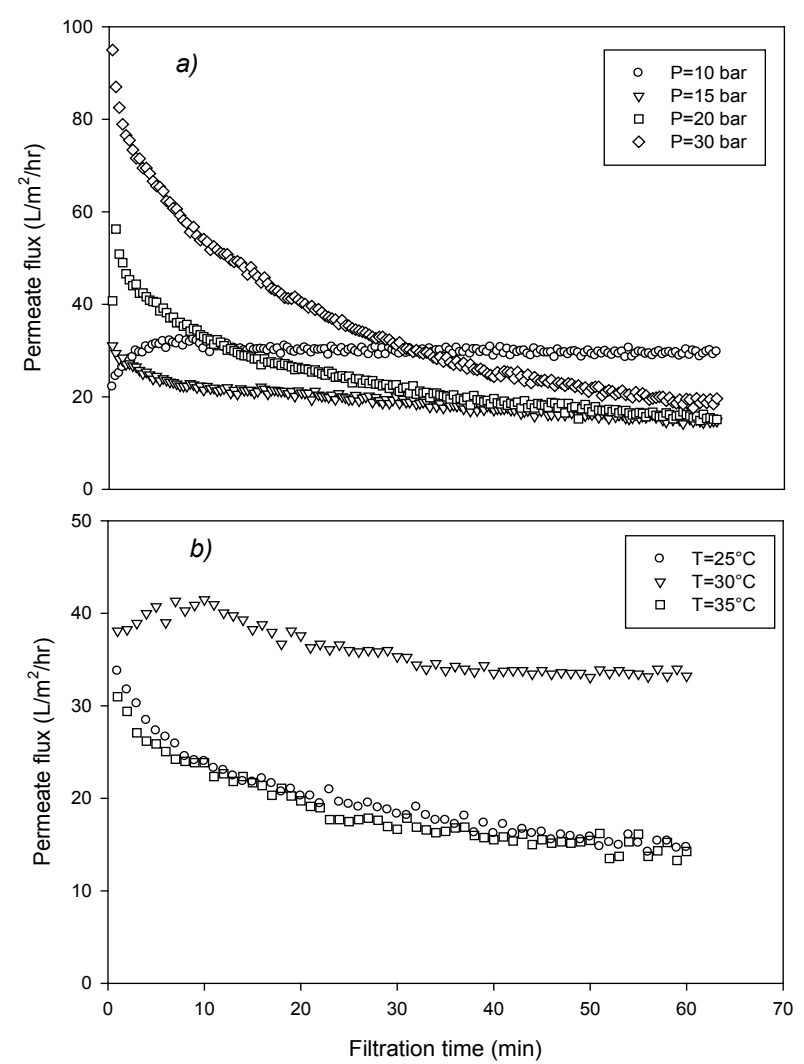

Figure 3: Permeate flux decline with time (a) at four different feed pressures of 10 bar $(\circ), 15$ bar $(\sigma), 20$ bar $(\leq)$, and 30 bar $(\diamond)$ for X20 membrane (Test conditions employed were suspended solid concentration : $1,072 \mathrm{mg} / \mathrm{L}$, crossflow velocity : $2.0 \mathrm{~m} / \mathrm{s}$, temperature : $25 \pm 1^{\circ} \mathrm{C}$, and $\mathrm{pH}: 7.3 \pm 0.2$ )

(b) at three different feed temperatures $25^{\circ} \mathrm{C}(\circ), 30^{\circ} \mathrm{C}(\sigma)$, and $35^{\circ} \mathrm{C}(\leq)$ for X20 membrane (Test conditions employed were suspended solid concentration : $1,072 \mathrm{mg} / \mathrm{L}$, cross-flow velocity : $2.0 \mathrm{~m} / \mathrm{s}, \mathrm{P}: 10$ bar and $\mathrm{pH}: 7.3 \pm 0.2$ ).

\section{Removal of contaminants}

The performances of NF and RO membranes were evaluated and compared in terms of removal of various contaminants such as COD, $\mathrm{TN}, \mathrm{NO}_{2}-\mathrm{N}, \mathrm{NO}_{3}-\mathrm{N}, \mathrm{NH}_{4}-\mathrm{N}, \mathrm{TP}$. The quality of composite permeates obtained from experiments at different NF and RO membranes were compared with the corresponding feed values in Table 3 . As seen from Table 3, $\mathrm{COD}$ and $\mathrm{NO}_{3}-\mathrm{N}$ removal values were found to be between $79 \%$ and $99 \%$. In terms of COD removal, it was seen that NF90, BW30, SW30 and X20 membranes showed the highest efficiency values (99\%); similarly these membranes were also able to achieve $\mathrm{NO}_{3}-\mathrm{N}$ removal efficiency over $98 \%$. NP010 membrane resulted in the worst COD removal reducing the influent COD from $4610 \mathrm{mg} / \mathrm{L}$ down to 976 $\mathrm{mg} / \mathrm{L}$. On the other hand, the best effluent COD value was achieved by SW30 membrane $(24 \mathrm{mg} / \mathrm{L})$. While X20 resulted in lowest $\mathrm{NO}_{3}-\mathrm{N}$ residual $(0.26 \mathrm{mg} / \mathrm{L})$ in the permeate, NP010 membrane was the worst one with a residual concentration of $22.9 \mathrm{mg} / \mathrm{L}$. Furthermore, all membranes tested in this study were found to be quite successful for the removal of both $\mathrm{NO}_{2}-\mathrm{N}$ and TP with removal efficiency over $98 \%$. Table 3 shows that while NP010 again performed the worst $\mathrm{NH}_{4}-\mathrm{N}$ and TN removal (584 mg/L and $1090 \mathrm{mg} / \mathrm{L}$ ), X20 outperformed all other membranes with residual $\mathrm{NH}_{4}-\mathrm{N}$ and $\mathrm{TN}$ concentrations of 23 and $93 \mathrm{mg} / \mathrm{L}$, respectively. The best residual concentrations of $\mathrm{NO}_{2}-\mathrm{N}$ and TP were $0.03 \mathrm{mg} / \mathrm{L}$ (X20 membrane) and $0.17 \mathrm{mg} / \mathrm{L}$ (X20 membrane), respectively. In conclusion, the best quality of permeate in terms of especially nitrogen species removal was obtained by X20 membrane which showed satisfactory specifications for the water recovery as fresh water use. Even though RO membrane performed best amongst the all membranes tested in this study, NF 90 also showed remarkable results especially in terms of $\mathrm{TN}(83 \%)$ and $\mathrm{NH}_{4}-\mathrm{N}(82 \%)$ removal. In fact, according to the results obtained in this study, NF90 membrane seems that it could even be used alone with no much need for RO. On the other hand, if it is used in combination with RO membrane, in addition to its high ammonia removal, it would also provide a good pretreatment for RO to prevent fouling, maximize membrane life, and increase flux. Viau and Normandin [27] reported 52\% and $78 \%$ of Total Ammonia-Nitrogen (TAN) and potassium removal, respectively by an NF membrane $(150 \mathrm{Da})$ operating at $2.1 \mathrm{MPa}$ in the effluent from an aerobic reactor fed pig manure [27]. The results obtained in our study were found to be better than this literature report.

\section{Final remarks}

In order to realize the idea of recycling digester effluent as fresh feed water and eliminating the need for the construction of costly final storage tank for digestate, the integration of membrane filtration system to conventional anaerobic digestion flow scheme, a new and novel approach, namely CLAMBS approach (Closed Loop Anaerobic Membrane System), is introduced for the first time in this study. As seen in Figure 4, the proposed flow scheme as a modification of conventional biogas system is composed of membrane filtration unit equipped with the membrane types which were tested and selected in this study. As it is seen, this approach allows the use of digestate back in the process continuously and eliminates the costly construction of huge final storage tanks. This approach not only provides the aforementioned advantages but also prevents potential environmental deteriorations due to the intensive land application of digestate having high loads of nutrients and other organic materials. Last but not least, concentrated retentate which is rich in nutrients ( $\mathrm{N}$ and $\mathrm{P}$ ) could also be sold as liquid fertilizer. 


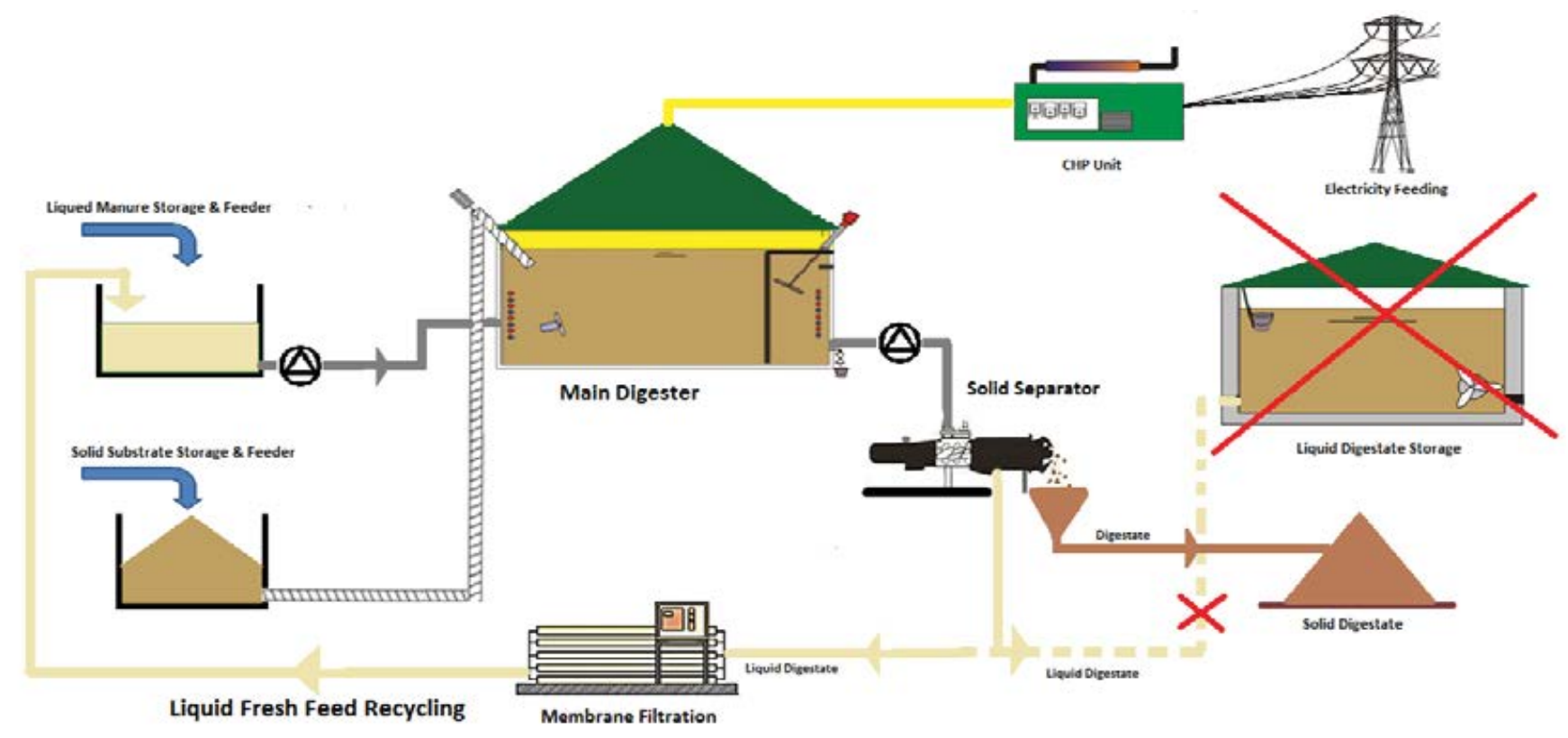

Figure 4: Flowscheme of proposed CLAMBS process

\section{Conclusions}

The feasibility of TN and ammonia removal from anaerobic digester effluent and continuous reuse of digestate as fresh feed water was suggested. For this purpose, NF90 and X20 type membranes were found to be most effective for the recovery of ammonium from the digestate, which would allow the use of this concentrated retentate as a liquid fertilizer. Problems associated with surplus nutrients in areas with high livestock density could be solved by the use of membrane technology to concentrate manure nutrients in small volumes that could be exported as fertilizer to other agricultural regions. This novel approach would be suggested as an alternative method for biogas production from chicken manure as mono substrate. It looks like that the use of membrane supported biogas production systems could provide a sustainable solution for the needs of poultry industry. This new approach allows the continuous use of anaerobic digestate over and over as dilution water. Furthermore, it also eliminates the construction of tremendously large storage basins, which are needed as an essential part of conventional biogas plants.

\section{Acknowledgement}

The authors wish to thank TUBITAK-CAYDAG under the grant No 111 Y019 for the financial support of this study. The data presented in this article was produced within the project above, however it is only the authors of this article who are responsible for the results and discussions made herein.

\section{References}

1. Sutton MA, Dragosits U, Tang YS, Fowler D (2000) Ammonia emissions from non-agricultural sources in the UK. Atmospheric Environment 34: 855-869.

2. Rostron WM, Stuckey DC, Young AA (2001) Nitrification of high strength ammonia wastewaters: comparative study of immobilisation media. Water Res 35: 1169-1178.

3. Salminen E, Rintala J, Härkönen J, Kuitunen M, Högmander H, et al. (2001) Anaerobically digested poultry slaughterhouse wastes as fertiliser in agriculture. Bioresour Technol 78: 81-88.

4. Vukcevic S (1997) The mechanism of gold extraction and copper precipitation from low grade ores in cyanide ammonia systems. Minerals Engineering 10 309-326.
5. Abouelenien F, Kitamura Y, Nishio N, Nakashimada Y (2009) Dry anaerobic ammonia-methane production from chicken manure. Appl Microbiol Biotechnol 82: 757-764

6. Fang HY, Chou MS, Huang CW (1993) Nitrification of ammonia-nitrogen in refinery wastewater. Water Research 27: 1761-1765.

7. Rajagopal R, Massé DI, Singh G (2013) A critical review on inhibition of anaerobic digestion process by excess ammonia. Bioresour Technol 143: 632-641.

8. Ahn Y-H (2006) Sustainable nitrogen elimination biotechnologies: A review Process Biochemistry 41: 1709-1721.

9. Dong X, Tollner EW (2003) Evaluation of Anammox and denitrification during anaerobic digestion of poultry manure. Bioresour Technol 86: 139-145.

10. Egli KR (2003) On the use of anammox in treating ammonium-rich wastewater Dipl. Mikrobiol. Universität Zürich, Zürich.

11. Jorgensen TC, Weatherley LR (2003) Ammonia removal from wastewater by ion exchange in the presence of organic contaminants. Water Res 37: 1723-1728.

12. Rozic M, Cerjan-Stefanovic S, Kurajica S, Vancina V, Hodzic E (2000) Ammoniacal nitrogen removal from water by treatment with clays and zeolites. Water Research 34: 3675-3681.

13. Pressley TA, Bishop DF, Roan SG (1972) Ammonia-nitrogen removal by breakpoint chlorination. Environ Sci Technol 6: 622-628.

14. Quan X, Wang F, Zhao Q, Zhao T, Xiang J (2009) Air stripping of ammonia in a water-sparged aerocyclone reactor. J Hazard Mater 170: 983-988.

15. Karabelas AJ, Yiantsios SG, Metaxiotou Z, Andritsos N, Akiskalos A, et al. (2001) Water and materials recovery from fertilizer industry acidic effluents by membrane. Desalination 138: 93-102.

16. Kurama H, Poetzschke J, Haseneder R (2002) The application of membrane filtration for the removal of ammonium ions from potable water. Water Res 36 2905-2909.

17. Masse L, Massé DI, Pellerin Y (2007) The use of membranes for the treatment of manure: a critical literature review. Biosystems Engineering 98: 371-380.

18. Noworytaa A, Koziolb T, Trusek-Holownia A (2003) A system for cleaning condensates containing ammonium nitrate by the reverse osmosis method. Desalination 156: 397-402.

19. Skouteris G, Hermosilla D, López P, Negro C, Blanco Á (2012) Anaerobic membrane bioreactors for wastewater treatment: A review. Chemical Engineering Journal 198-199: 138-148. 
Citation:Karaalp d, Doruk N, Dizge N, Keskinler B, Azbar N (2015) A Novel Solution for Biogas Applications in Poultry Industry: CLAMBS approach. J Bioprocess Biotech 5: 200 doi:10.4172/2155-9821.1000200

20. Bujoczek G, Oleszkiewicz J, Sparling R, Cenkowski S (2000) High Solid Anaerobic Digestion of Chicken Manure. Journal of Agricultural Engineering Research 76: 51-60.

21. Nghiem LD, Hawkes S (2007) Effects of membrane fouling on the nanofiltration of pharmaceutically active compounds (PhACs): Mechanisms and role of membrane pore size. Separation and Purification Technology 57: 176-184.

22. Van Der Bruggen B, Vandecasteele C (2001) Flux decline during nanofiltration of organic components in aqueous solution. Environ Sci Technol 35: 3535-3540.

23. Antony A, Low JH, Gray S, Childress AE, Le-Clech P, et al. (2011) Scale formation and control in high pressure membrane water treatment systems: $A$ review. Journal of Membrane Science 383: 1-16.
24. Kaya Y, Gönder ZB, Vergili I, Barlas H (2010) The effect of transmembrane pressure and $\mathrm{pH}$ on treatment of paper machine process waters by using a twostep nanofiltration process: Flux decline analysis. Desalination 250: 150-157.

25. Fernández E, Benito JM, Pazos C, Coca J (2005) Ceramic membrane ultrafiltration of anionic and nonionic surfactant solutions. Journal of Membrane Science 246: 1-6.

26. Sharma RR, Agrawal R, Chellam S (2003) Temperature effects on sieving characteristics of thin-film composite nanofiltration membranes: pore size distributions and transport parameters. Journal of Membrane Science 223: 69-87.

27. Viau JM, Normandin Y (1990) E' tude sur le traitement de polissage par osmose inverse de l'effluent de la station pilote de Saint-Elze'ar pour le traitement du lisier de porc (Study on tertiary treatment by reverse osmosis of the effluent from the pilot station of St-Elze'ar for swine manure treatment). Que'bec MdIEedIFd, ed. (Qc, Canada). 